\title{
Helicobacter pylori in early childhood and asthma in adolescence
}

\author{
Kjetil K. Melby ${ }^{1,3^{*}}$, Karin L. Carlsen²,3, Geir Håland², Helvi H. Samdal ${ }^{1}$ and Kai-Håkon Carlsen ${ }^{3}$
}

\begin{abstract}
Objective: An inverse effect of Helicobacter pylori (H. pylori) on the occurrence of asthma is debated and early acquisition of H. pylori may be important. We analyzed sera from 197 children from Environment and Childhood Asthma (ECA) study in Oslo for Helicobacter pylori (H. pylori) at 2 and 10 years, and symptoms and signs of asthma at 16 years of age.

Results: While $16.4 \%$ of children who were H. pylori negative at 2 and 10 years had current asthma at 16 years, none of the 12 children who were $H$. pylori positive at 2 years of age had asthma at the age of 16 years, regardless of H. pylori status at 10 years. This trend for less current asthma in children who were H. pylori positive at 2 years compared to persistent or transient negative status at 10 years was not statistically significant, probably due to low number of $H$. pylori positive children at 2 years of age. Acquisition of H. pylori in school age did not appear to influence the risk of current asthma. Much larger prospective studies are probably required to document whether or not early H. pylori infection may be involved in the risk of asthma development in later childhood.
\end{abstract}

Keywords: Anti H. pylori lgG antibodies, Asthma in adolescence, Cohort study, H. pylori carriage in children and adolescence, Helicobacter pylori

\section{Introduction}

The role of Helicobacter pylori (H. pylori) in asthma and atopy development is debated [1-3]. Some studies report reduced risk of asthma in children with IgG antibodies against $H$. pylori (H. pylori positive) [4, 5], while a metaanalysis of 770 cases and 785 controls concluded with no significant association between asthma and $H$. pylori carriage [6], and a recent study suggesting that $H$. pylori infection diagnosed in adults above 20 years of age may experience an increase in the risk of adult onset asthma [7]. In the Environment and Childhood Asthma (ECA) birth cohort study in Oslo with a prevalence of current asthma of $13.7 \%$ at 16 years of age [8] we recently showed that presence of IgG antibodies against Helicobacter pylori (H. pylori) as well as IgG antibodies against cagA at

\footnotetext{
*Correspondence: k.k.melby@medisin.uio.no

${ }^{3}$ Faculty of Medicine, Institute of Clinical Medicine, University of Oslo,

Oslo, Norway

Full list of author information is available at the end of the article
}

16 years of age was associated with the absence of current asthma [9], and that most cagA positive individuals had high levels of H. pylori IgG antibodies [9]. Cross sectional studies have demonstrated inverse associations with current asthma in 3-13 year-old children and adults [4] and a meta-analyses observed a weak, but significant inverse associations in children and adults [5]. Also, in Ethiopian children, $H$. pylori positivity was associated with reduced risk of "any allergic condition" at 6 years, while at 3 years, H. pylori positive children had non-significantly more often wheeze and significantly less atopic dermatitis than $H$. pylori negative children $[10,11]$.

As there is limited knowledge of the associations between $H$. pylori IgG in early childhood and asthma in adolescence, we aimed to examine if the presence of $H$. pylori IgG at 2 and 10 years of age was associated with current asthma at in adolescence.

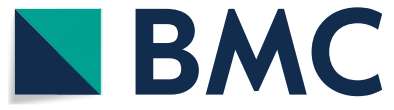

(c) The Author(s) 2020. This article is licensed under a Creative Commons Attribution 4.0 International License, which permits use, sharing, adaptation, distribution and reproduction in any medium or format, as long as you give appropriate credit to the original author(s) and the source, provide a link to the Creative Commons licence, and indicate if changes were made. The images or other third party material in this article are included in the article's Creative Commons licence, unless indicated otherwise in a credit line to the material. If material is not included in the article's Creative Commons licence and your intended use is not permitted by statutory regulation or exceeds the permitted use, you will need to obtain permission directly from the copyright holder. To view a copy of this licence, visit http://creativeco mmons.org/licenses/by/4.0/. The Creative Commons Public Domain Dedication waiver (http://creativecommons.org/publicdomain/ zero/1.0/) applies to the data made available in this article, unless otherwise stated in a credit line to the data. 


\section{Main text}

From the asthma enriched general population ECA study [8] we included all 197 children who attended the 2-10 and 16 year follow-up investigations and had $H$. pylori analyses performed at the time of sampling at 2 and 10 years. Serum was analyzed in a conventional Enzyme Immunosorbent Assay (EIA) for anti $H$. pylori IgG antibodies and the results were classified as positive, borderline or negative all according to the manufacturer's instructions (Orion Diagnostica, Espoo, Finland). An estimate of quantity of anti $H$. pylori IgG was also recorded in keeping with the manual following the assay. Anti-H. pylori IgG: negative $(<17)$, borderline (17-22), positive $(\geq 23)$, all given in arbitrary units

Table 1 The Hp status at 2 and 10 years is shown in relation to current asthma (yes or no) at 16 years among 197 children

\begin{tabular}{llc}
\hline Hp status 2 years & Hp status 10 years & $\begin{array}{l}\text { Current } \\
\text { asthma } \\
\mathbf{1 6} \text { years } \\
\text { N/n } \text { at } 2 \text { years } \\
\mathbf{( \% )}\end{array}$ \\
\hline Negative $n=183$ & Negative $n=172$ & $30 / 183(16.4)$ \\
Borderline $n=2$ & Positive $n=11$ & $1 / 183(0.6)$ \\
Positive $n=12$ & Negative $n=1$ & $0 / 2(0)$ \\
Total & Positive $n=1$ & $1 / 2(50)$ \\
& Negative $n=7$ & $0 / 12(0)$ \\
& Positive $n=5$ & $0 / 12(0)$ \\
& & $32 / 197(16.2)$
\end{tabular}

(AU). Current asthma at 16 years of age was defined as a positive response to at least two of the following three structured interview questions within the last 12 months: wheeze or shortness of breath, asthma medications and a doctor diagnosis of asthma [12]. Risk of current asthma by $H$. pylori status was compared by the $\chi^{2}$ test and statistical significance was set to $0.05 \%$. All analyses were done in IBM SPSS version 25.

Twelve children were anti $H$. pylori IgG positive by the age of 2 years, of whom five remained positive also at 10 years. The majority of $H$. pylori IgG negative children $(94 \%)$ of children, who were $H$. pylori IgG negative at 2 years, were negative also at 10 years. None of the 12 children who had H. pylori IgG at 2 years of age had current asthma at 16 years regardless of $H$. pylori IgG status at 10 years, compared to $17 \%$ of the $H$. pylori negative children and one of the two children with borderline H. pylori positive at 2 years (Table 1$)$ ( $p>0.1$ by $x^{2}$ test). Among the two children with current asthma at 16 years and $H$. pylori IgG at 10 years, one was negative and one borderline $H$. pylori IgG positive at 2 years of age. Their antibody levels to $H$. pylori were low in contrast to the other $H$. pylori positives patients who were non-asthmatic. At 10 years 17 children had positive H. pylori IgG antibodies with titers ranging 20-653 (Fig. 1).

The finding that none of the H. pylori seropositive children at 2 years had current asthma in adolescence is in line with previous reports [3-5]. Our results are further supported by studies in mice showing that infection with H. pylori in the neonatal period prevented asthma development later in life. Importantly, primary infection with

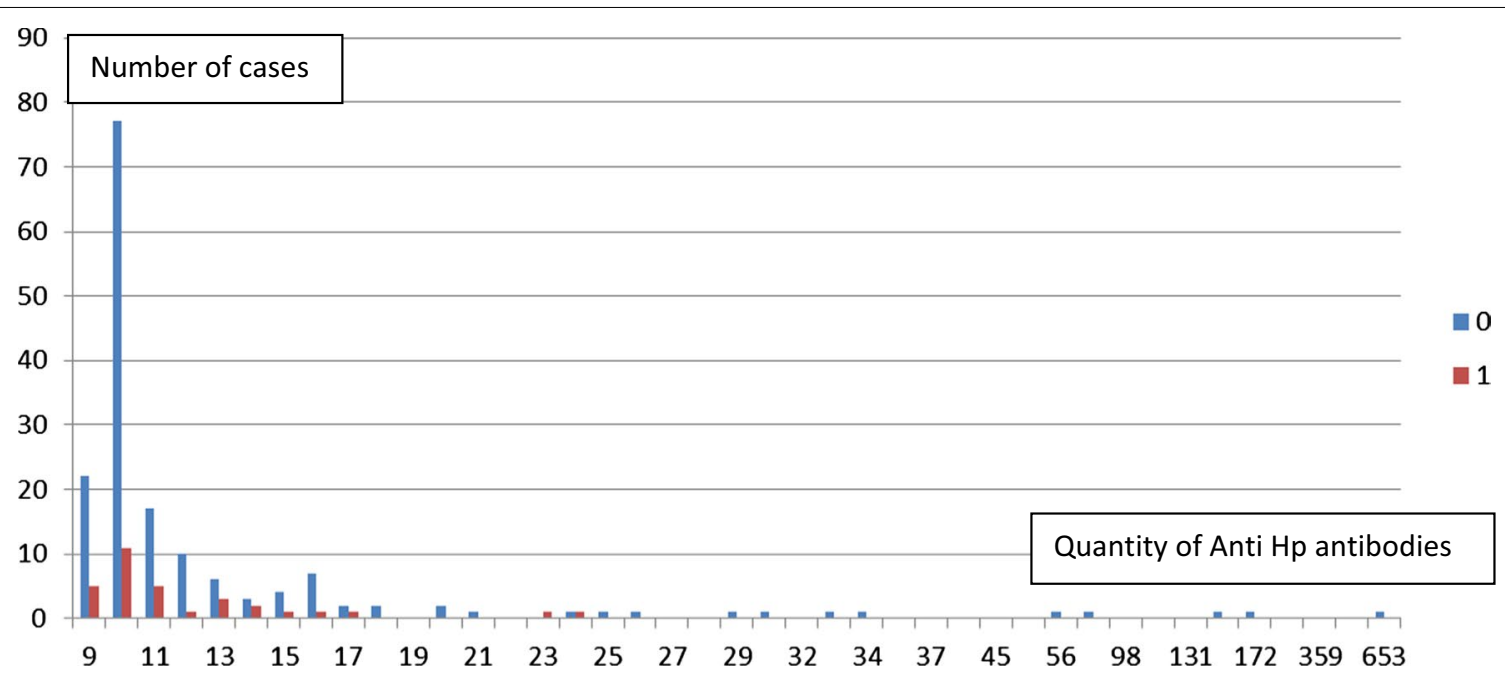

Fig. 1 Serum levels of IgG antibodies against Helicobacter pylori at 10 years of age in a group of 197 children followed from 2 to 16 years of age in relation to presence $(1=$ Red $)$ or absence $(0=$ Blue) of current asthma at the age of 16 . The two children with current asthma and positive Hp lgG at 10 years were $\mathrm{Hp}$ negative and $\mathrm{Hp}$ borderline at 2 years, respectively. Anti-Hp IgG: negative $(<17)$, borderline (17-22), positive ( $\geq 23)$. All given in arbitrary units (AU) 
H. pylori in grown up mice, on the other hand, showed no such protective effect [13], in line with the recent increased risk of adult onset asthma in H. pylori infected individuals [7]. During the first years of life an adaption between the microbiome and the host takes place. The outcome of this interaction is regarded to be of substantial importance and ending in most cases in a delicate balance between the host immune system and the established microbiome. In developing countries the exposure to a microbiome containing $H$. pylori is common whereas in more affluent societies this is more seldom [14]. Our aim was to examine whether a significant inverse relationship between $H$. pylori and the occurrence of asthma could be demonstrated in our cohort. It is most likely that the microbiome/diet in a Nordic setting differs from a variety of African environments in which the carriage rate of $H$. pylori is higher. The presence of $H$. pylori in the Scandinavian communities at large is low [14]. Interestingly, none of the children with high levels of anti $H$. pylori antibodies suggesting brisk inflammatory response to $H$. pylori had current asthma. Whether other species and other microbiomes such as the skin microbiome may have a decisive role as a player in the control of the immune response resulting in a lower frequency of atopy and/or asthma as suggested by Finnish studies remains to be settled $[15,16]$. Our results do not statistically support the hypothesis that there is an inverse relationship between the presence of $H$. pylori suggesting that early presence of $H$. pylori in this context is beneficial. However, the lack of asthma in high level H. pylori positive cases might justify further studies in areas where the prevalence of $H$. pylori, preferably carrying cagA, is higher. A real difference in occurrence of asthma and atopy was reported in the Karelian area with a Finnish and Russian area having similar climatic condition. Interestingly, the difference observed, i.e. low incidence of asthma and atopy in Russia compared to the Finnish sector, suggests that other factors, possibly related to differences in socioeconomic conditions, may in part explain these observations [15]. Furthermore Miftahussurur et al. reported that variation in carriage rate of $H$. pylori was not inversely related to asthma [2]. In conclusion, adolescent current asthma was not observed in any of the $12 \mathrm{H}$. pylori seropositive children at 2 years of age, regardless of $H$. pylori positive or negative status at 10 years in this prospective birth cohort study with a prevalence of current asthma of $13.7 \%$. This may indicate that acquisition of $H$. pylori per se or a microbiome with presence of $H$. pylori at the age of 2 or less might prove beneficial.

\section{Limitations}

Our results do not statistically support the hypothesis that there is an inverse relationship between the presence of $H$. pylori suggesting that early presence of $H$. pylori in this context is beneficial. Much larger prospective studies are probably required to document whether or not early $H$. pylori infection may be involved in the risk of asthma development in later childhood.

\section{Abbreviations \\ ECA study: Environment and Childhood Asthma (ECA) birth cohort study in Oslo; H. pylori: Helicobacter pylori; H. pylori positive: Child with IgG antibodies against H. pylori.}

\section{Acknowledgements}

We thank all the children and their parents for willingness to establish and follow up this cohort of children making this study possible.

\section{Authors' contributions}

KKM conceived the ideas of reviewing previous obtained data from the cohort and had a major role in the preparation and discussion of the data and manuscript. KLC had a major role in the preparation and discussion of the data and manuscript. GH was involved in the clinical part of the cohort used, and is the principle investigator of the ECA study. HHS together with KKM was responsible for the serology studies. K-HC participated in the preparation and discussion of the data. All authors read and approved the final manuscript.

\section{Funding}

No specific funding was provided for this study on the data generated in the ECA study [8]. The funding bodies played no part in the design of the present study, neither in collection, analysis, and interpretation of data already at hand, nor in writing the manuscript.

Availability of data and materials

Enquiries as to availability of data and material in this cohort should be addressed to KCLC.

\section{Ethics approval and consent to participate}

The study is a part of The Environment and Childhood Asthma Study in Oslo and has been approved by the Regional Committee for Medical and Health Research Ethics, South East Norway. Both parents gave a written consent to having their child included in the study at the time the mother and child were to leave the hospital after delivery. Thereafter written consent to follow up studies was given at 6 months, one, 2, 10 and by 16 years of age. At the age of 16 the children also gave their written consent to participate in the study.

Consent to publish

Not applicable.

\section{Competing interests}

The authors have no competing interests.

\section{Author details \\ ${ }^{1}$ Department of Microbiology, Oslo University Hospital, 0035 Oslo, Norway. 2 Division of Pediatric and Adolescent Medicine, Oslo University Hospital, 0407 Oslo, Norway. ${ }^{3}$ Faculty of Medicine, Institute of Clinical Medicine, Univer- sity of Oslo, Oslo, Norway.}

Received: 28 June 2019 Accepted: 6 February 2020

Published online: 18 February 2020

\section{References}

1. Kalach N, Bontems P, Raymond J. Helicobacter pylori infection in children. Helicobacter. 2017:22(Suppl 1):e12414. 
2. Miftahussurur M, Nusi IA, David Y, Graham DY, Yamaoka Y. Helicobacter, hygiene, atopy, and asthma. Front Microbiol. 2017:8:1034. https://doi. org/10.3389/fmicb.2017.01034.

3. Roma E, Miele E. Helicobacter pylori infection in pediatrics. Helicobacter. 2015;20(Suppl 1):47-53.

4. Chen Y, Blaser MJ. Helicobacter pylori colonization is inversely associated with childhood asthma. J Infect Dis. 2008;198:553-60.

5. Blaser MJ, Chen Y, Reibman J. Does Helicobacter pylori protect against asthma and allergy? Gut. 2008:57:561-7.

6. Wang Y, Bi Y, Zhang L, Wang C. Is Helicobacter Pylori infection associated with asthma risk? A meta-analysis based on 770 cases and 785 controls. Int J Med Sci. 2012;9(7):603-10. https://doi.org/10.7150/ijms.4970.

7. Wang Y-C, Lin T-Y, Shang S-T, Chen H-J, Kao C-H, Wu C-C, Yang TY. Helicobacter pylori infection increases the risk of adult-onset asthma: a nationwide cohort study. Eur J Clin Microbiol Infect Dis. 2017;36:1587-94.

8. Hovland V, Riiser A, Mowinckel P, Carlsen KH, Carlsen KC. Asthma with allergic comorbidities in adolescence is associated with bronchial responsiveness and airways inflammation. Pediatr Allergy Immunol. 2014;25:351-9.

9. Melby KK, Carlsen KL, Haaland G, Samdal HH, Mowinckel P, Carlsen KH. Antibody levels to Helicobacter pylori infections at 16 years of age in relation to allergic disease. Helicobacter. 2017;22(Suppl 1):114.

10. Amberbir A, Medhin G, Abegaz WE, Hanlon C, Robinson K, Fogarty A, et al. Exposure to Helicobacter pylori infection in early childhood and the riskof allergic disease and atopic sensitization: a longitudinal birth cohort study. Clin Exp Allergy. 2014;44:563-71.

11. Taye B, Enquselassie F, Tsegaye A, Amberbir A, Medhin G, Fogarty A, et al. Association between infection with Helicobacter pylori and atopy in young Ethiopian children: a longitudinal study. Clin Exp Allergy. 2017:47:1299-308.

12. Berents TL, Carlsen KCL, Mowinckel P, Skjerven HO, Rolfsjord LB, Nordhagen LS, Kvenshagen B, Hunderi JOG, Bradley M, Thorsby PM, Carlsen $\mathrm{KH}, \mathrm{Gjersvik}$ P. Weight-for-length, early weight-gain velocity and atopic dermatitis in infancy and at 2 years of age: a cohort study. BMC Pediatr. 2017. https://doi.org/10.1186/s12887-017-0889-6.

13. Arnold IC, Dehzad N, Reuter S, Martin H, Becher B, Taube C, et al. Helicobacter pylori infection prevents allergic asthma in mouse models through the induction of regulatory T cells. J Clin Invest. 2011;121:3088-93.

14. Melby KK, Lødrup Carlsen KC, Håland G, Samdal HH, Mowinckel P, Carlsen $\mathrm{K}-\mathrm{H}$. Cod liver oil consumption and prevalence of Helicobacter pylori $(\mathrm{H}$. pylori) infections at 2, 10 and 16 years of age. Helicobacter. 2017;22(Suppl 1):96-7.

15. Haahtela T, Laatikainen T, Alenius H, Auvinen P, Fyhrquist P, Hanski I, et al. Hunt for the origin of allergy — comparing the Finnish and Russian Karelia. Clin Exp Allergy. 2015;45:891-901.

16. Kosunen TU, Höök-Nikanne J, Salomaa A, Sarna S, Aromaa A, Haahtela T. Increase of allergen-specific immunoglobulin E antibodies from 1973 to 1994 in a Finnish population and a possible relationship to Helicobacter pylori infections. Clin Exp Allergy. 2002;32:373-8.

\section{Publisher's Note}

Springer Nature remains neutral with regard to jurisdictional claims in published maps and institutional affiliations.
Ready to submit your research? Choose BMC and benefit from:

- fast, convenient online submission

- thorough peer review by experienced researchers in your field

- rapid publication on acceptance

- support for research data, including large and complex data types

- gold Open Access which fosters wider collaboration and increased citations

- maximum visibility for your research: over 100M website views per year

At BMC, research is always in progress.

Learn more biomedcentral.com/submissions 